\title{
Improvement in Surface Fatigue Life of Hardened Gears by High-Intensity Shot Peening
}

Dennis P. Townsend

Lewis Research Center

Cleveland, Ohio

Prepared for the

Sixth International Power Transmission and Gearing Conference sponsored by the American Society of Mechanical Engineers

Scottsdale, Arizona, September 13-16, 1992 



\title{
IMPROVEMENT IN SURFACE FATIGUE LIFE OF HARDENED GEARS
}

\section{BY HIGH-INTENSITY SHOT PEENING}

\author{
Dennis P. Townsend \\ National Aeronautics and Space Administration \\ Lewis Research Center \\ Cleveland, Ohio 44135
}

\section{SUMMARY}

Two groups of carburized, hardened, and ground spur gears that were manufactured from the same heat of vacuum-inductionmelted-vacuum-arc-remelted (VIM-VAR) AISI 9310 steel were endurance tested for surface fatigue. Both groups were manufactured with a standard ground 16-rms surface finish. One group was subjected to a shot-peening intensity of 7 to $9 \mathrm{~A}$, and the second group was subjected to a shot-peening intensity of 15 to $17 \mathrm{~A}$ All gears were honed after shot peening to a surface finish of $16 \mathrm{rms}$. The gear pitch diameter was $8.89 \mathrm{~cm}$ (3.5 in.). Test conditions were a maximum Hertz stress of $1.71 \mathrm{GPa}(248 \mathrm{ksi})$, a gear temperature of $350 \mathrm{~K}\left(170^{\circ} \mathrm{F}\right)$, and a speed of $10000 \mathrm{rpm}$. The lubricant used for the tests was a synthetic paraffinic oil with an additive package. The following results were obtained: The 10-percent surface fatigue (pitting) life of the high-intensity (15 to $17 \mathrm{~A}$ ) shot-peened gears was 2.15 times that of the medium-intensity ( 7 to $9 \mathrm{~A}$ ) shot-peened gears, the same as that calculated from measured residual stress at a depth of $127 \mu \mathrm{m}$ ( $5 \mathrm{mil})$. The measured residual stress for the highintensity-shot-peened gears was 57 percent higher than that for the medium-intensity-shot-peened gears at a depth of $127 \mu \mathrm{m}(5 \mathrm{mil})$ and 540 percent higher at a depth of $51 \mu \mathrm{m}(2 \mathrm{mil})$.

\section{INTRODUCTION}

Shot peening has been used for several decades to improve the t.ending fatigue properties of numerous applications (Moore, 1944; Valentine, 1948; Straub, 1964). Some of these applications include the improvement of the bending strength of gear teeth (Aida, 1966; Kirk et al., 1966). Studies of residual stresses in rolling-element bearings have shown that increasing residual compressive stress will increase the surface fatigue life (Zaretsky, 1967; Zaretsky et al., 1967; Cretu, 1987). In an earlier work (Townsend et al., 1982) the effect of shot peening on the surface fatigue life of carburized and hardened spur gears was studied. In that study the gears were shot peened to a 7 to $9 \mathrm{~A}$ intensity, which increased the compressive residual stress enough to increase the gear surface fatigue life by a factor of 1.6 over that for gears that were not shot peened.

Therefore it was decided to evaluate the effect of shot peening carburized and hardened gears to a higher intensity. This higher intensity shot peening should further increase the compressive stress in the gear teeth over that produced by the medium-intensity shot peening. The results of Townsend et al. (1982) suggest that this increased compressive stress should extend the surface fatigue life of the gears. If an improvement in the surface fatigue life of gears is obtained by shot peening to a higher intensity, the goal of more durable and more reliable aircraft gearing for helicopters and other aircraft will be realized.

The objectives of the research reported herein were (1) to investigate how high-intensity shot peening of gear teeth with hard shot affects the surface fatigue life of case-carburized, hardened, and ground AISI 9310 steel spur gears, (2) to compare the life of the higher-intensity-shot-peened gears with that of gears manufactured with the same material and specifications and shot peened to a lower intensity, and (3) to determine the residual stress produced by the shot peening and its effect on the surface fatigue life of the gears.

To accomplish these objectives, two groups of gears were manufactured from a single heat of vacuum-induction-meltedvacuum-arc-remelted (VIM-VAR) AISI 9310 gear material. Both groups of gears were case carburized, hardened, and ground. After grinding, one group of test gears was shot peened to a high intensity and the second group was shot peened to a medium intensity. Both groups of gears were honed after shot peening to improve the surface finish. The gear pitch diameter was $8.89 \mathrm{~cm}$ (3.5 in.). Both groups of gears were tested to fatigue by surface pitting under identical test conditions. These test conditions included a gear temperature of $350 \mathrm{~K}\left(170^{\circ} \mathrm{F}\right)$, a maximum Hertz stress of $1.71 \mathrm{GPa}(248 \mathrm{ksi})$, and a speed of $10000 \mathrm{rpm}$.

\section{APPARATUS, SPECIMENS, AND PROCEDURE}

\section{Gear Test Apparatus}

The gear fatigue tests were performed in the NASA Lewis Research Center's gear test apparatus (Fig. 1). This test rig uses the four-square principle of applying the test gear load so that the input drive only needs to overcome the frictional losses in the system. 


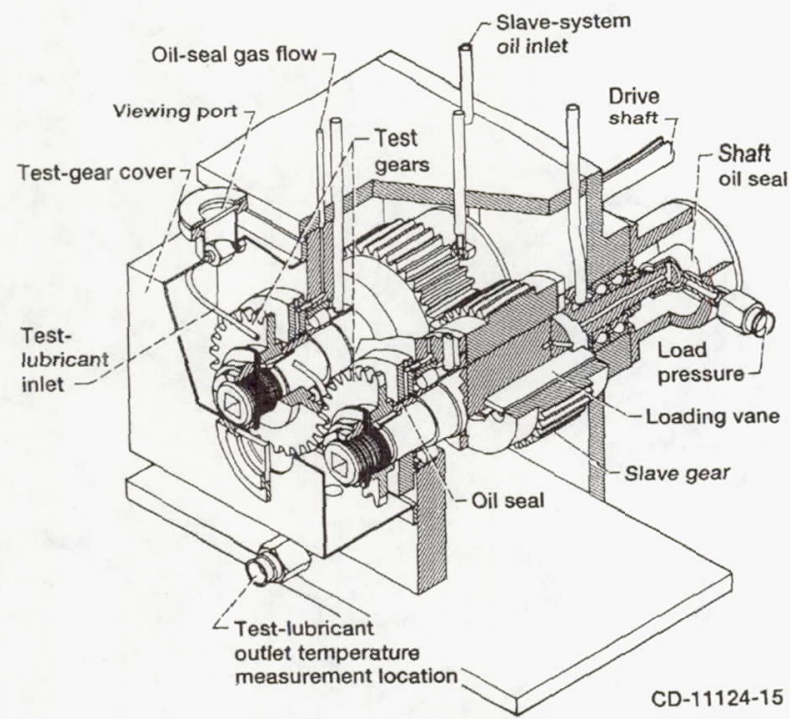

(a) Cutaway view.

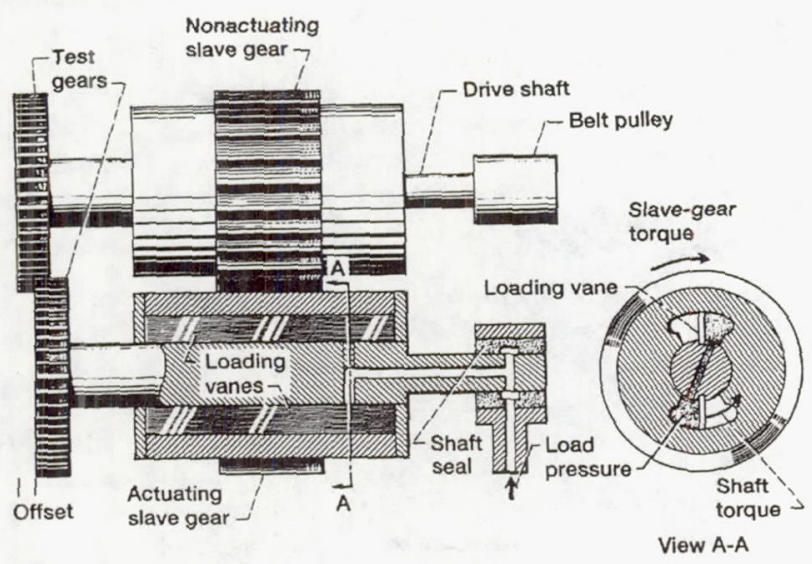

$C D-11421-15$

(b) Schematic diagram.

Figure 1. -NASA Lewis Research Center's gear fatigue test apparatus.

A schematic of the test rig is shown in Fig. 1(b). Oil pressure and leakage flow are supplied to the load vanes through a shaft seal. As the oil pressure is increased on the load vanes inside the slave gear, the loop torque is applied. This torque is transmitted through the test gears back to the slave gear, where an equal but opposite torque is maintained by the oil pressure. This torque on the test gears, which depends on the hydraulic pressure applied to the load vanes, loads the gear teeth to the desired contact or Hertz stress level. The two identical test gears can be started under no load, and the load can be applied gradually, without changing the running track on the gear teeth.

Separate lubrication systems are provided for the test gears and the main gearbox. The two lubrication systems are separated at the gearbox shafts by pressurized labyrinth seals. Nitrogen is the seal gas. The test gear lubricant is filtered through a $5-\mu \mathrm{m}$-nominal fiberglass filter. The test lubricant can be heated electrically with an immersion heater. The temperature of the heater is controlled to prevent overheating of the test lubricant.

A vibration transducer mounted on the gearbox is used to automatically shut off the test rig when a gear surface fatigue occurs. The gearbox is also automatically shut off if there is a loss of oil flow to either the main gearbox or the test gears, if the test gear oil overheats, or if there is a loss of seal gas pressurization.

The belt-driven test rig can be operated at several fixed speeds by changing pulleys. The operating speed for the test reported herein was $10000 \mathrm{rpm}$.

\section{Test Materials}

The test gears were manufactured from VIM-VAR AISI 9310 steel from the same heat of material. Both sets of gears wert case hardened to Rockwell $\mathrm{C} 60$ at a depth of $0.97 \mathrm{~mm}$ (0.038 in.). The nominal core hardness was Rockwell C 35 . The chemical composition of the material is given in Table I. Both sets of gears were case carburized and heat treated in accordance with the heat treatment schedule of Table II. Figure 2 shows the case and core microstructure of an etched and polished AISI 9310 gear tooth surface.

\section{Test Gears}

The dimensions of the test gears are given in Table III. All gears had a nominal surface finish on the tooth face of $0.406 \mu \mathrm{m}$ (16 $\mu$ in.) $\mathrm{rms}$ and a standard $20^{\circ}$ involute profile with tip relief. The linear tip relief was $0.0013 \mathrm{~cm}(0.0005 \mathrm{in}$.), starting at the highest point of single-tooth contact. One set of the gears was shot peened to a medium intensity, and the second set of gears was shot peened to a high intensity. Both sets of gears were shot peened

TABLE I--NOMINAL
CHEMICAL COMPO-
SITION OF VIM-
VAR AISI 9310
GEAR MATERIAL
\begin{tabular}{|c|c|}
\hline Element & Composition \\
& wt \% \\
\hline $\mathrm{C}$ & 0.10 \\
$\mathrm{Mn}$ & .63 \\
$\mathrm{Si}$ & .27 \\
$\mathrm{Ni}$ & 3.22 \\
$\mathrm{Cr}$ & 1.21 \\
$\mathrm{Mo}$ & .12 \\
$\mathrm{Cu}$ & .13 \\
$\mathrm{P}$ & .005 \\
$\mathrm{~S}$ & .005 \\
\hline
\end{tabular}

TABLE II.-HEAT TREATMENT SCHEDULE FOR AISI 9310

\begin{tabular}{|c|c|c|c|c|}
\hline \multirow[t]{2}{*}{ Step } & \multirow[t]{2}{*}{ Process } & \multicolumn{2}{|c|}{ Temperature } & \multirow{2}{*}{$\begin{array}{c}\text { Time, } \\
\text { hr }\end{array}$} \\
\hline & & $\mathrm{K}$ & ${ }^{\circ} \mathrm{F}$ & \\
\hline 1 & Preheat in air & $\ldots$ & --- & -.-- \\
\hline 2 & Carburize & 1172 & 1650 & 8 \\
\hline 3 & $\begin{array}{l}\text { Air cool to room } \\
\text { temperature }\end{array}$ & $-\ldots$ & --- & $\ldots$ \\
\hline 4 & Copper plate all over & $\cdots$ & $\cdots$ & $\cdots$ \\
\hline 5 & Reheat & 922 & 1200 & 2.5 \\
\hline 6 & $\begin{array}{l}\text { Air cool to room } \\
\text { temperature }\end{array}$ & --- & --- & -.o- \\
\hline 7 & Austenitize & 1117 & 1550 & 2.5 \\
\hline 8 & Oil quench & $-\cdots$ & $\ldots$ & $\ldots$ \\
\hline 9 & Subzero cool & 180 & -120 & 3.5 \\
\hline 10 & Double temper & 450 & 350 & 2 each \\
\hline 11 & Finish grind & -.-- & $\ldots$ & ב- \\
\hline 12 & Stress relieve & 450 & 350 & 2 \\
\hline
\end{tabular}




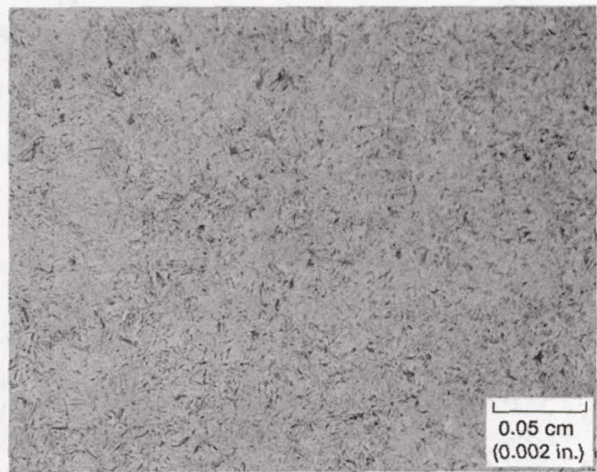

(a) Case.

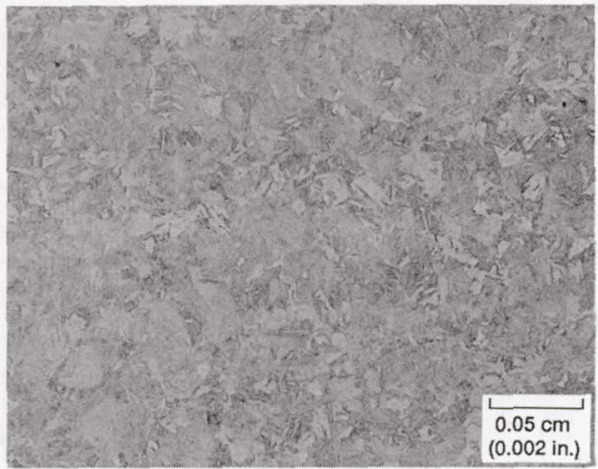

(b) Core.

Figure 2.-Photomicrographs of case and core for AISI 9310 shot-peened spur gears.

\section{TABLE III.-SPUR GEAR DATA}

[Gear tolerance per ASMA class 12.

Number of teeth . . . . . . . . . . 28

Diametral pitch . . . . . . . . . . . . . 8

Circular pitch, cm (in.) . . . . . 0.9975 (0.3927)

Whole depth, cm (in.) . . . . . . . $0.762(0.300)$

Addendum, cm (in.) . . . . . . . . 0.318 (0.125)

Chordal tooth thickness . . . . . . 0.485 (0.191)

(reference), $\mathrm{cm}$ (in.)

Pressure angle, $\operatorname{deg} \ldots \ldots \ldots \ldots \ldots . \ldots 20$

Pitch diameter, $\mathrm{cm}$ (in.) . . . . . . 8.890 (3.500)

Outside diameter, $\mathrm{cm}$ (in.) . . . . . . 9.525 (3.750)

Root fillet, $\mathrm{cm}$ (in.) . . . . . . . 0.102 to 0.152

(0.04 to 0.06 )

Measurement over pins, cm (in.) . . 9.603 to 9.630

(3.7807 to 3.7915$)$

Pin diameter, $\mathrm{cm}$ (in.) . . . . . . . $0.549(0.216)$

Backlash reference, cm (in.) . . . . $0.0254(0.010)$

Tip relief, cm (in.) . . . . . . . . 0.001 to 0.0015

$(0.0004$ to 0.0006$)$

Tooth width, cm (in.) . . . . . . $0.635(0.25)$

after finish grinding on the tooth root and the tooth profile according to the specifications for specimens 1 and 3 given in Table IV. The effect of the shot peening on the surface of the ends of the teeth is shown in Fig. 3. The ends of the teeth have a hardened edge and a softer core. Shot peening had more severe effects on the softer core than on the hardened edge of the tooth. The gears were honed after shot peening to a surface finish of 16 rms.

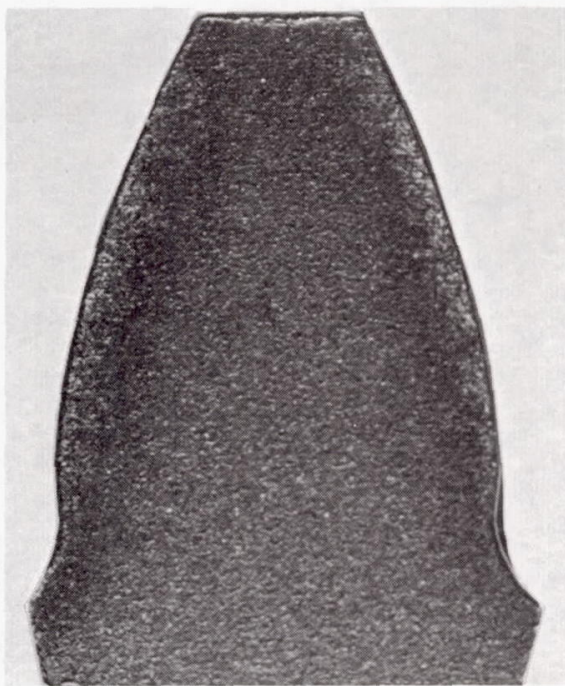

(a) Medium-intensity shot peening.

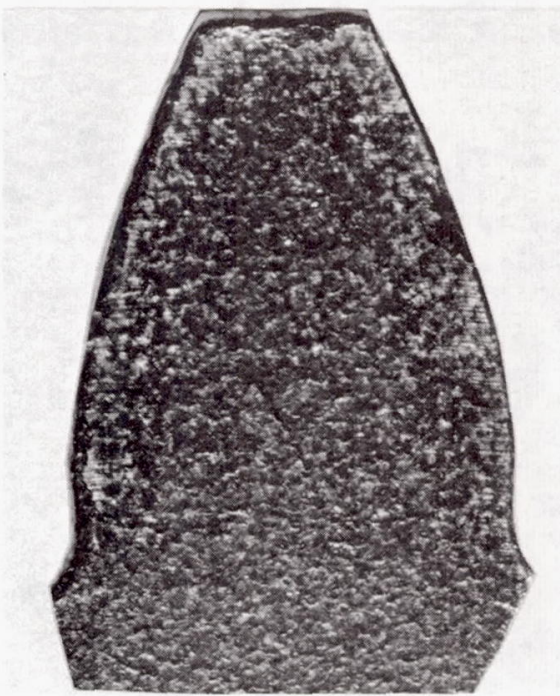

(b) High-intensity shot peening.

Figure 3,-Ends of gear teeth showing effect of shot peening on surface of case and core material.

\section{$\underline{\text { Test Lubricant }}$}

All the gears were lubricated with a single bath of synthetic paraffinic oil. The physical properties of this lubricant are summarized in Table V. Five percent of an extreme-pressure additive, designated Lubrizol 5002 (partial chemical analysis given in Table V), was added to the lubricant.

\section{Test Procedure}

After the test gears were cleaned to remove the preservative, they were assembled on the test rig. The $0.635-\mathrm{cm}(0.25$-in.) wide test gears were run in an offset condition with a $0.30-\mathrm{cm}(0.12-i n$.) tooth-surface overlap to give a load surface on the gear face of $0.28 \mathrm{~cm}(0.11 \mathrm{in}$.), thereby allowing for the edge radius of the gear teeth. If both faces of the gears were tested, four fatigue tests could be run for each set of gears. All tests were run in at a pitch-line load of $1225 \mathrm{~N} / \mathrm{cm}(700 \mathrm{lb} / \mathrm{in}$.) for $1 \mathrm{hr}$, producing a maximum Hertz stress of $0.756 \mathrm{GPa}(111 \mathrm{ksi})$. The load was then increased to $5784 \mathrm{~N} / \mathrm{cm}(3305 \mathrm{lb} / \mathrm{in}$.), producing a pitch-line maximum Hertz 


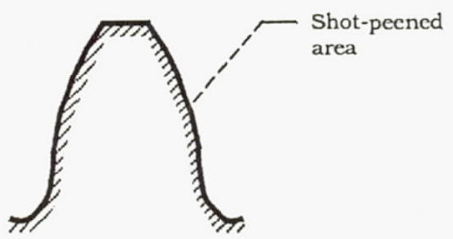

[Specification, MIL-S-131658, BPS FW 4409.]

\begin{tabular}{|c|c|c|c|}
\hline & \multicolumn{3}{|c|}{ Gear specimen } \\
\hline & 1 & 2 & 3 \\
\hline Shot size & 070 & 070 & 330 \\
\hline Shot type & Cast steel & Cast steel & Cast steel \\
\hline Intensity (height of & 0.18 to 0.23 & 0.18 to 0.23 & 0.38 to 0.43 \\
\hline $\begin{array}{l}\text { Almen strip, type A), } \\
\text { mm (in.) }\end{array}$ & $(0.007$ to 0.009$)$ & (0.007 to 0.0 .009$)$ & (0.015 to 0.017$)$ \\
\hline $\begin{array}{l}\text { Coverage (sides and } \\
\text { root only), percent }\end{array}$ & 200 & 100 & 200 \\
\hline
\end{tabular}

\section{TABLE V.-PROPERTIES OF SYNTHETIC PARAFFINIC OIL}

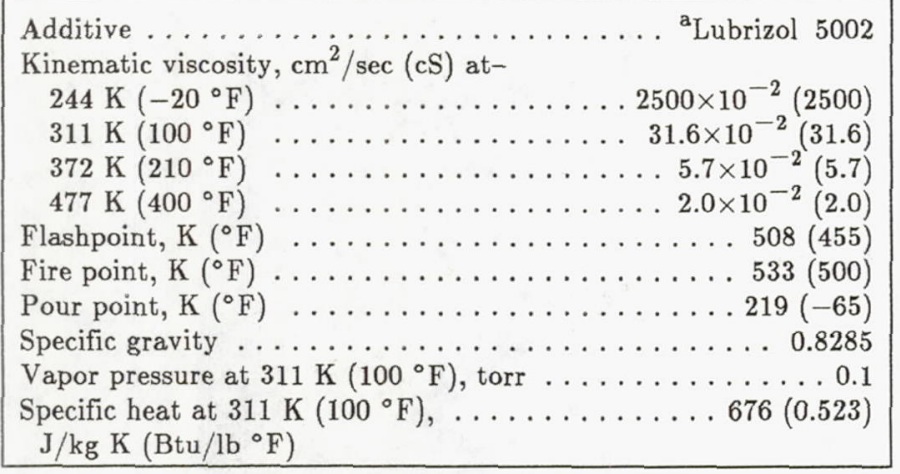

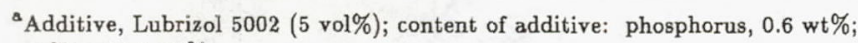
sulfur, $18.5 \mathrm{wt} \%$.

stress of $1.71 \mathrm{GPa}(248 \mathrm{ksi})$ if plain bending is assumed. However, because there was an offset load, an additional stress was imposed on the tooth bending stress. Combining the bending and torsional moments gave a maximum stress of $0.26 \mathrm{GPa}(37 \mathrm{ksi})$. This bending stress did not include the effects of tip relief, which would also increase the bending stress.

Operating the test gears at $10000 \mathrm{rpm}$ gave a pitch-line velocity of $46.55 \mathrm{~m} / \mathrm{sec}(9163 \mathrm{ft} / \mathrm{min})$. Lubricant was supplied to the inlet mesh at $800 \mathrm{~cm}^{3} / \mathrm{min}(0.21 \mathrm{gpm})$ at $319 \pm 6 \mathrm{~K}$ $\left(116^{\circ} \pm 10^{\circ} \mathrm{F}\right)$. The lubricant outlet temperature was nearly constant at $350 \pm 3 \mathrm{~K}\left(170^{\circ} \pm 5^{\circ} \mathrm{F}\right)$. The tests ran continuously $(24 \mathrm{hr} /$ day $)$ until they were automatically shut down by the vibration detection transducer, which was located on the gearbox adjacent to the test gears. The lubricant circulated through a $5-\mu \mathrm{m}$ fiberglass filter to remove wear particles. After each test the lubricant and the filter element were discarded. Inlet and outlet oil temperatures were continuously recorded on a strip-chart recorder.

The pitch-line elastohydrodynamic (EHD) film thickness was calculated by the method of Dowson and Higginson (1966). It was assumed, for this film thickness calculation, that the gear temperature at the pitch line was equal to the outlet oil temperature and that the inlet oil temperature to the contact zone was equal to the gear temperature, even though the inlet oil temperature was considerably lower. It is possible that the gear surface temperature was even higher than the outlet oil temperature, especially at the end points of sliding contact. The EHD film thickness for these conditions was computed to be $0.33 \mu \mathrm{m}(13 \mu \mathrm{in}$.), which gave an initial ratio of film thickness to composite surface roughness $\mathrm{h} / \sigma$ of 0.55 at the 1.71-GPa (248-ksi) pitch-line maximum Hertz stress.

\section{RESULTS AND DISCUSSION}

Two lots of vacuum-induction-melted-vacuum-arc-remelted (VIM-VAR) AISI 9310 steel gears were tested in pairs until failure; in some cases the testing was suspended after $500 \mathrm{hr}$ without failure. One lot of gears was shot peened to a 7 to $9 \mathrm{~A}$ intensity (medium intensity), and the other group was shot peened to a 15 to $17 \mathrm{~A}$ intensity (high intensity). Both groups of gears were honed to $16 \mathrm{rms}$ after shot peening. Twenty gears were tested in each lot. There were 14 failures and six 500-hr suspensions in the mediumintensity-shot-peened gears. There were 13 failures and seven 500 -hr suspensions in the high-intensity-shot-peened gears. Test results were analyzed by considering the life of each pair of gears as a system.

Surface fatigue (pitting) life results for the medium-intensityshot-peened AISI 9310 gears are shown in Fig. 4(a). These data were analyzed by the method of Johnson (1964). The 10- and 50 -percent lives were $42 \times 10^{6}$ and $142 \times 10^{6}$ stress cycles (70 and $236 \mathrm{hr}$ ), respectively. The failure index (i.e., the number of fatigue failures out of the number of tests) was 14 out of 20 . The slope of the Weibull line is 1.56. A typical fatigue spall is shown in Fig. 5(a). A cross section of a typical fatigue spall is shown in Fig. 5(b). The surface fatigue (pitting) failure originated below the surface in the region of maximum shear stress. Surface fatigue (pitting) life results for the AISI 9310 gears that were shot peened to high intensity are shown in Fig. 4(b). The 10- and 50-percent fatigue lines were $89 \times 10^{6}$ and $246 \times 10^{6}$ stress cycles (148 and $410 \mathrm{hr}$ ), respectively. The failure index was 13 out of 20 with seven 500-hr suspensions. The slope of the Weibull line is 1.86. A typical fatigue spall is shown in Fig. 6(a). A cross section of the fatigue spall is shown in Fig. 6(b). These results are summarized in Table VI. The high-intensity-shot-peened gears exhibited a 10-percent fatigue life that was 2.15 times that of the gears that were shot peened to medium intensity. The confidence number for the difference in life was 83 percent, which indicates that the life difference is statistically significant. The mean life ratio for the high-intensity-shot-peened gears over the medium-intensity-shot- 


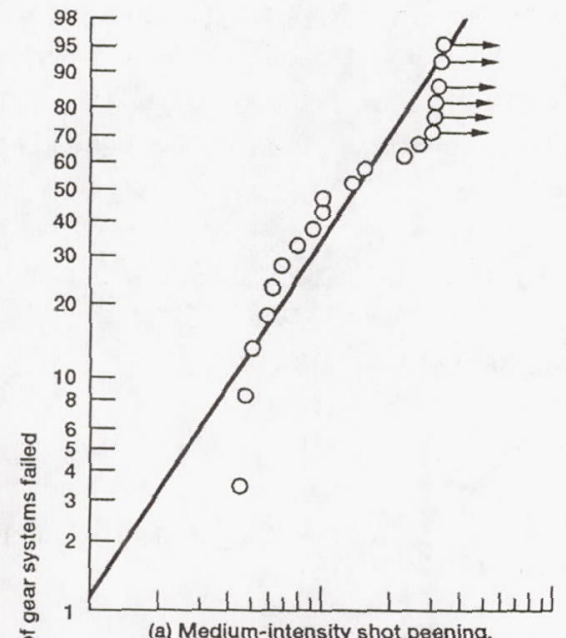

(a) Medium-intensity shot peening.

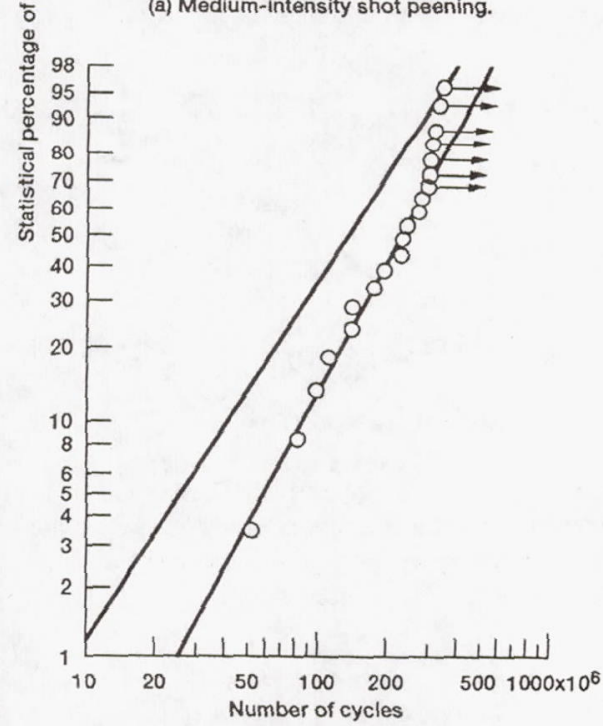

(b) High-intensity shot peening.

Figure 4.-Comparison of surface (pitting) fatigue lives of standard ground and shot-peened carburized and hardened CVM AISI 9310 steel spur gears. Speed, $10000 \mathrm{~mm}$; lubricant, synthetic paraffinic oil; gear temperature, $350 \mathrm{~K}\left(170^{\circ} \mathrm{F}\right)$; maximum Hertz stress, $1.71 \mathrm{GPa}(248 \mathrm{ksi})$

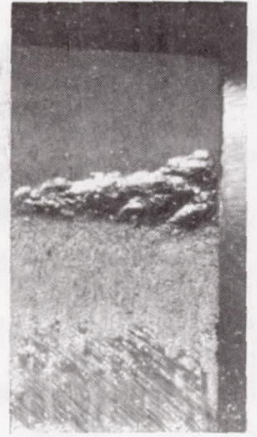

(a) Typical fatigue spall.

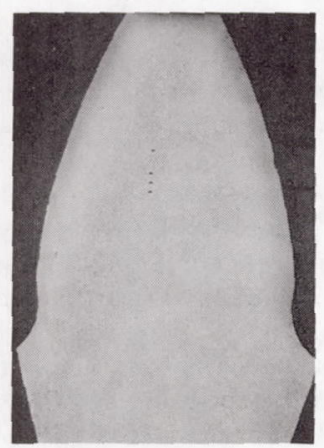

(b) Cross section.
Figure 5.-Fatigue spall for medium-intensity-shot-peened gears.

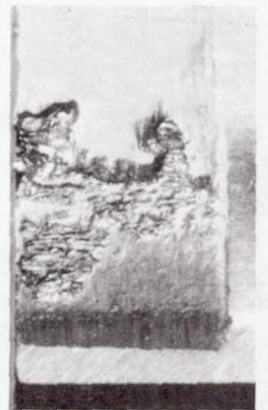

(a) Typical tatigue spall.

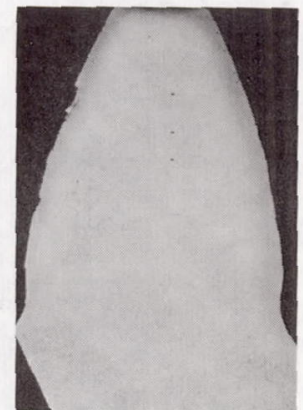

(b) Cross section.
Figure 6.-Fatigue spall for high-intensity-shot-peened gears.

TABLE VI.-FATIGUE RESULTS WITH AISI 9310 SHOT-PEENED TEST GEARS

\begin{tabular}{|c|c|c|c|c|c|}
\hline Gears & $\begin{array}{c}\text { 10-Percent } \\
\text { life } \\
\text { cycles }\end{array}$ & $\begin{array}{c}50 \text {-Percent } \\
\text { life, } \\
\text { cycles }\end{array}$ & Slope & $\begin{array}{c}\text { Failure } \\
\text { index }^{\mathrm{a}}\end{array}$ & $\begin{array}{c}\text { Confidence } \\
\text { number, } \\
\text { percent }\end{array}$ \\
\hline $\begin{array}{c}\text { Medium } \\
\text { intensity } \\
\text { High } \\
\text { intensity }\end{array}$ & $82 \times 10^{6}$ & $142 \times 10^{6}$ & 1.56 & $14 / 20$ & -- \\
\hline
\end{tabular}

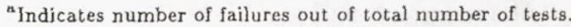

bProbability, expressed as a percentage, that the 10-percent life with the baseline AISI 9310 gears is either less than, or greater than, that of the particular lot of gears being considered.

peened gears was 1.7 with a confidence number of 98 percent. The confidence number indicates the percentage of time the relative lives of the gears will occur in the same order.

The gears tested in Townsend et al. (1982) that were shot peened with medium-hard shot had a compressive residual stress approximately 10000 psi higher than non-shot-peened gears in the region of maximum shear stress produced by the gear tooth contact load. For these tests the calculated life improvement based on the measured residual stress was about equal to the experimental life improvement. From these results it was theorized that a further improvement in surface fatigue life could be obtained if the shotpeening intensity were increased enough to increase residual stress to a much higher level than that obtained for the gears used in Townsend et al. (1982).

Therefore, three gears were shot peened with different shot and intensities as shown in Table IV. Two residual stress measurements were made on each of the three gears on two teeth $180^{\circ}$ apart. These measurements were made at the surface and at nominal depths below the surface of $25,51,76,127,178,250$, and $330 \mu \mathrm{m}$ $(1,2,3,5,7,10$, and 13 mil). The method of x-ray stress measurement and the calibration procedures are described in Christenson (1971) and Prevey (1977). Two of these gears were selected for the shot-peening condition used for the two sets of gears tested: one with low-intensity shot peening and one with highintensity shot peening. These two conditions were 1 and 3 from Table IV.

The residual stress was measured on one gear from each of the two sets of gears. These measurements are shown in Fig. 7. The residual stress in the region of maximum shear stress for the medium-intensity-shot-peened gears (Fig. 7(a)) was very close to that of the shot-peened gears used in Townsend et al. (1982). However, the hook in the curve near the surface was not present as it was in the earlier study. This may be the result of the honing operation, which removed a small amount of the surface material. 

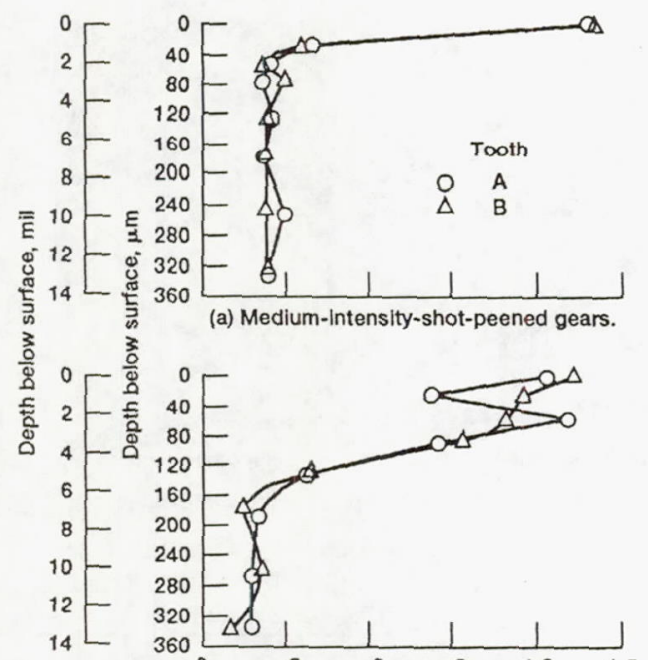

(a) Medium-Intensity-shot-peened gears.

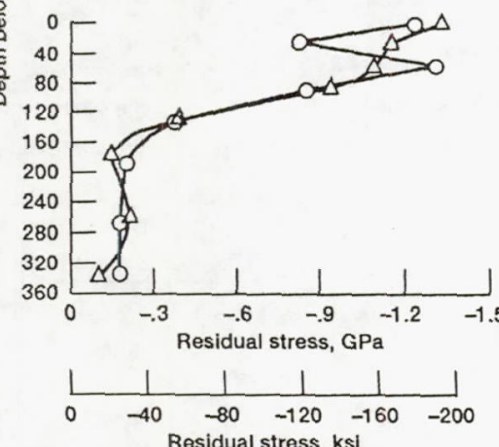

(b) High-intensity-shot-peened gears.

Figure 7.-Principal residual stress as a function of depth below surface of carburized, hardened, ground, and untested AISI 9310 steel spur gear teeth.

The residual stress measurements for the high-intensity-shotpeened gears are shown in Fig. 7(b). The compressive residual stress in these gears did not decrease rapidly from the surface as it did in the medium-intensity-shot-peened gears and produced a much higher compressive residual stress 25 to $152 \mu \mathrm{m}$ ( 1 to $6 \mathrm{mil}$ ) below the surface. At a depth of $51 \mu \mathrm{m}(2 \mathrm{mil})$ the residual compressive stress for the high-intensity-shot-peened gears was 540 percent that for the medium-intensity-shot-peened gears.

The depth to the maximum shear stress for the load condition used in this program would be $170 \mu \mathrm{m}$ ( $7 \mathrm{mil}$ ) without considering the effect of friction or traction, which produces a force on the surface of the gear teeth that is normal to the applied load. Smith and Liu (1953) have shown that a traction coefficient of $1 / 9$ in a rolling sliding contact will cause the maximum shear stress to be located on the surface of the contact. The coefficient of friction for spur gears with good accuracy and fine finish varies from 0.01 to 0.05 (Buckingham, 1963; Kelley, 1953; and Anderson and Loewenthal, 1984).

The depth to the maximum shear stress would therefore be somewhat less than $170 \mu \mathrm{m}$ ( $7 \mathrm{mil})$ when the traction effect on the gear tooth is considered. It was therefore decided to determine at what depth the differences in residual stress produced by the different shot-peening methods would predict the same ratio of surface fatigue life for the experimental data for the two sets of gears. The equation given in Townsend et al. (1982) was used to determine the relative fatigue lives of the gears from the measured residual stress at different depths below the surface. At a depth of $126 \mu \mathrm{m}(5 \mathrm{mil})$ the residual stresses for the medium- and highintensity-shot-peened gears were 35 and $55 \mathrm{ksi}$ compressive, respectively, which is an increase of 57 percent for the high-intensity-shotpeened gears. Using the equations from the analysis given in Townsend et al. (1982), the maximum shear stress including the residual stress is

$$
\left(\tau_{\max }\right)_{\mathrm{r}}=-3.15 \times 10^{6}\left(\frac{\mathrm{P}_{\mathrm{N}}}{\mathrm{LS}_{\max } \mathrm{R}}\right)-\frac{1}{2} \mathrm{~S}_{\mathrm{ry}}
$$

where the equivalent radius $R=7.62 \mathrm{~mm}(0.3 \mathrm{in}$.$) , the maximum$ Hertz stress $\mathrm{S}_{\max }=1.71 \mathrm{GPa}(248 \mathrm{ksi})$, the ratio of normal load to width $\mathrm{P}_{\mathrm{N}} / \mathrm{L}=578375 \mathrm{~N} / \mathrm{m}\left(3305 \mathrm{lb} / \mathrm{in}\right.$.), and $\mathrm{S}_{\text {ry }}$ is the residual stress in the $\mathrm{y}$ direction. Therefore for high-intensitypeened gears, in SI units,

$$
\begin{aligned}
\left(\tau_{\max }\right)_{\mathrm{r}} & =-21.74 \times 10^{9} \frac{578375}{0.00762 \times 1.71 \times 10^{9}}-\frac{1}{2}\left(0.38 \times 10^{9}\right) \\
& =-0.776 \mathrm{GPa}
\end{aligned}
$$

In U.S. customary units,

$$
\left\langle\tau_{\max }\right\rangle_{\mathrm{r}}=-3.15 \times 10^{6} \frac{3305}{0.3 \times 248000}-\frac{1}{2}(-55000)=-112430 \mathrm{psi}
$$

And for medium-intensity-peened gears, in SI units,

$$
\begin{aligned}
\left(\tau_{\max }\right)_{\mathrm{r}} & =-21.74 \times 10^{9} \frac{578375}{0.00762 \times 1.71 \times 10^{9}}-\frac{1}{2}\left(0.24 \times 10^{9}\right) \\
& =-0.845 \mathrm{GPa}
\end{aligned}
$$

In U.S. customary units,

$$
\begin{aligned}
\left(\tau_{\max }\right)_{\mathrm{r}} & =-3.15 \times 10^{6} \frac{3305}{0.3 \times 248000}-\frac{1}{2}(-35000) \\
& =-122430 \mathrm{psi}
\end{aligned}
$$

The surface fatigue life for gears from Townsend et al. (1978) is inversely proportional to the maximum shear stress to the ninth power. The life calculated by using the measured residual stress at the $127-\mu \mathrm{m}(5-\mathrm{mil})$ depth is therefore

$$
\frac{\mathrm{L}_{10_{\mathrm{H}}}}{\mathrm{L}_{10_{\mathrm{M}}}}=\left[\frac{\left(\tau_{\max }\right)_{\mathrm{rM}}}{\left(\tau_{\max }\right)_{\mathrm{rH}}}\right]^{9}=\left(\frac{0.845 \times 10^{9}}{0.776 \times 10^{9}}\right)^{9}=2.15
$$

This life ratio is the same as the experimental life ratio, indicating that the maximum shear stress occurred at the depth selected for the analysis.

\section{SUMMARY OF RESULTS}

Two groups of carburized, hardened, and ground spur gears that were manufactured from the same heat of vacuum-inductionmelted-vacuum-arc-remelted (VIM-VAR) AISI 9310 steel were endurance tested for surface fatigue. Both groups were manufactured with a standard ground 16-rms surface finish. One group was subjected to a medium shot-peening intensity of 7 to $9 \mathrm{~A}$, and the second group was subjected to a high shot-peening intensity of 15 to $17 \mathrm{~A}$. Both groups of gears were honed after shot peening to a surface finish of $16 \mathrm{rms}$. The gear pitch diameter was $8.89 \mathrm{~cm}$ (3.5 in.). Test conditions were a maximum Hertz stress of $1.71 \mathrm{GPa}$ $(248 \mathrm{ksi})$, a gear temperature of $350 \mathrm{~K}\left(170^{\circ} \mathrm{F}\right)$, and a speed of $10000 \mathrm{rpm}$. The lubricant used for the tests was a synthetic paraffinic oil with an additive package. The following results were obtained:

1. The 10-percent surface fatigue (pitting) life of the highintensity-shot-peened gears was 2.15 times that of the gears that were shot peened to the medium intensity. 
2. The calculated 10 -percent surface fatigue life of the highintensity-shot-peened gears determined from measured residual stress was 2.15 times that for the medium-intensity-shot-peened gears on the basis of residual stress at a depth of $127 \mu \mathrm{m}$ ( 5 mil).

3. The measured residual stress for the high-intensity-shotpeened gears was 57 percent higher than that for the mediumintensity-shot-peened gears at a depth of $127 \mu \mathrm{m}$ (5 mil). At a depth of $51 \mu \mathrm{m}$ (2 mil) the high-intensity-shot-peened gears had a residual compressive stress that was 540 percent that for the medium-intensity-shot-peened gears.

\section{REFERENCES}

Aida, T., and Oda, S., 1966, "Bending Fatigue Strength of Gears," Japan Society of Mechanical Engineers, Bulletin, Vol. 9, pp. 793-806.

Anderson, N.E., and Loewenthal, S.H., 1984, "Efficiency of Nonstandard and High Contact Ratio Involute Spur Gears," NASA TM-83725, NASA Lewis Research Center, Cleveland, OH.

Buckingham, E., 1949, Analytical Mechanics of Gears, McGraw-Hill Book Co., New York.

Christenson, A.L., ed., 1971, Measurement of Stress by X-Ray, $\mathrm{SAE}$, New York.

Cretu, S.S., 1987, "Influence of Compressive Residual Stresses on Ball Bearing Fatigue Life, "Revue Roumaine des Sciences Techniques, Serie de Mecanique Appliquee, Vol. 32, pp. 547-560.

Dowson, D., and Higginson, G.R., 1966, Elastohydrodynamic Lubrication: the Fundamentals of Roller and Gear Lubrication, Pergamon Press, New York, p. 96.

Johnson, L.G., 1964, The Statistical Treatment of Fatigue Experiments, Elsevier Pub. Co., New York.

Kelley, B.W., 1953, "A New Look at the Scoring Phenomena of Gears," SAE Transactions, Vol. 61, pp. 175-188.
Kirk, D., Nelms, P.R., and Arnold, B., 1966, "Residual Stress and Fatigue Life of Case-Carburized Gears," Metallurgica, Vol. 76, p. 255.

Moore, H.F., 1944, Shot Peening and Fatigue of Metals, American Foundry Equipment Co., Mishawaka, IN.

Prevey, P.S., 1977, "A Method of Determining the Elastic Properties of Alloys in Selected Crystallographic Directions for XRay Diffraction Residual Stress Measurements," Advances in XRay Analysis, H.F. McMurdie, et al., eds., Plenum Press, New York, Vol. 20, pp. 345-354.

Smith, J.O., and Liu, C.K., 1953, "Stresses Due to Tangential and Normal Loads on an Elastic Solid With Application to Some Contact Stress Problems," Journal of Applied Mechanics, Vol. 20, pp. 157-166.

Straub, J.C., 1964, "Shot Peening in Gear Design," AGMA Paper 109.13 .

Townsend, D.P., Coy J.J., and Zaretsky, E.V., 1978, "Experimental and Analytical Load Life Relation for AISI 9310 Steel Spur Gears," Journal of Mechanical Design, Vol. 100, pp. 54-60.

Townsend, D.P., and Zaretsky, E.V., 1982, "Effect of Shot Peening on Surface Fatigue Life of Carburized and Hardened AISI 9310 Spur Gears," NASA TP-2047, NASA Lewis Research Center, Cleveland, $\mathrm{OH}$.

Valentine, K.B., 1948, "Recristallization as a Measurement of Relative Shot Peening Intensities," Transactions of the American Society for Metals, Vol. 40, pp. 420-434.

Zaretsky, E.V., et al., 1965, "Effects of Component Differential Hardness on Residual Stress and Rolling-Contact Fatigue," NASA TN D-2664, NASA Lewis Research Center, Cleveland, OH.

Zaretsky, E.V., Parker, R.J., and Anderson, W.J., 1967, "Component Hardness Differences and Their Effect on Bearing Fatigue," Journal of Lubrication Technology, Vol. 89, pp. 47-62. 


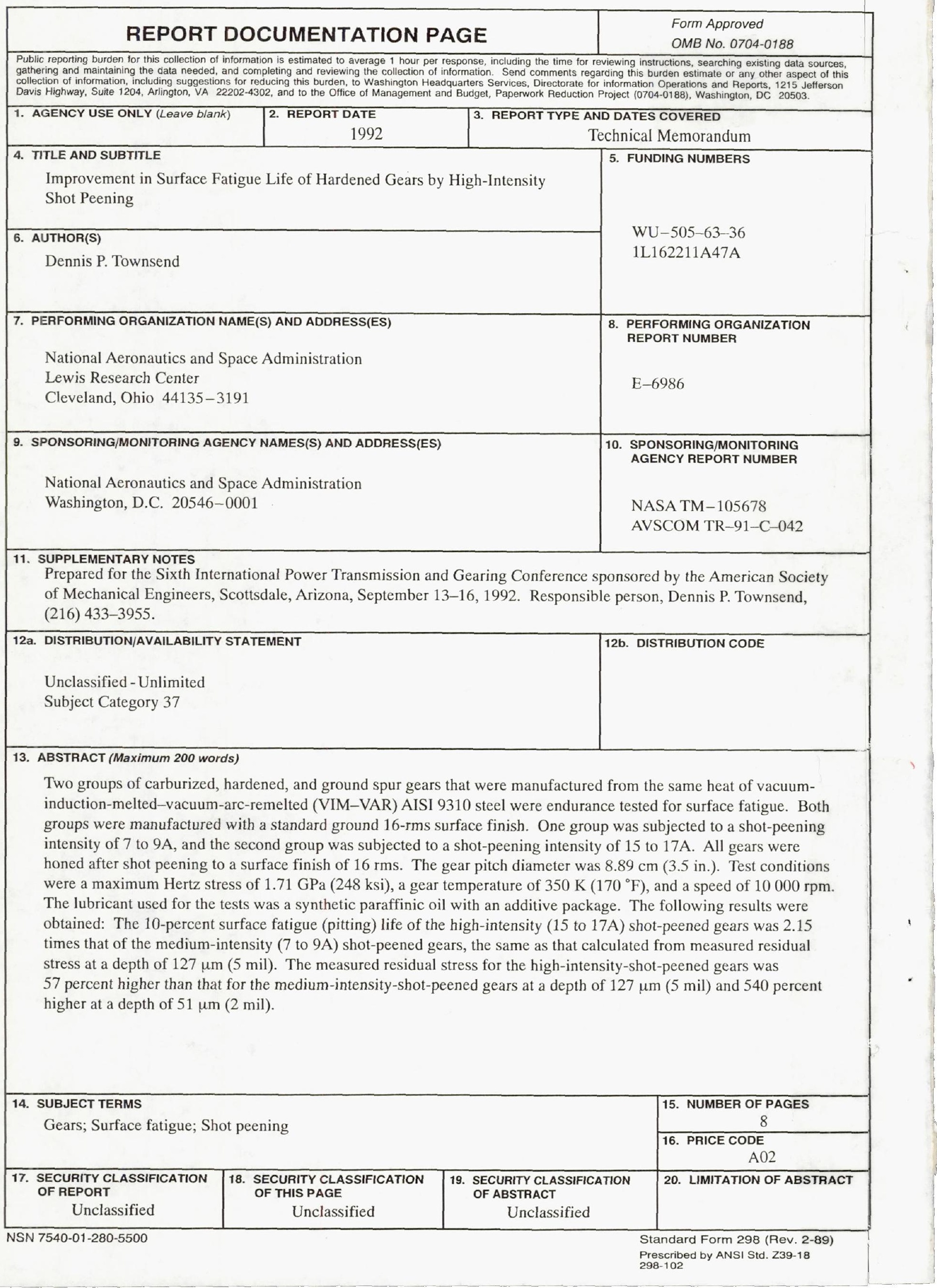




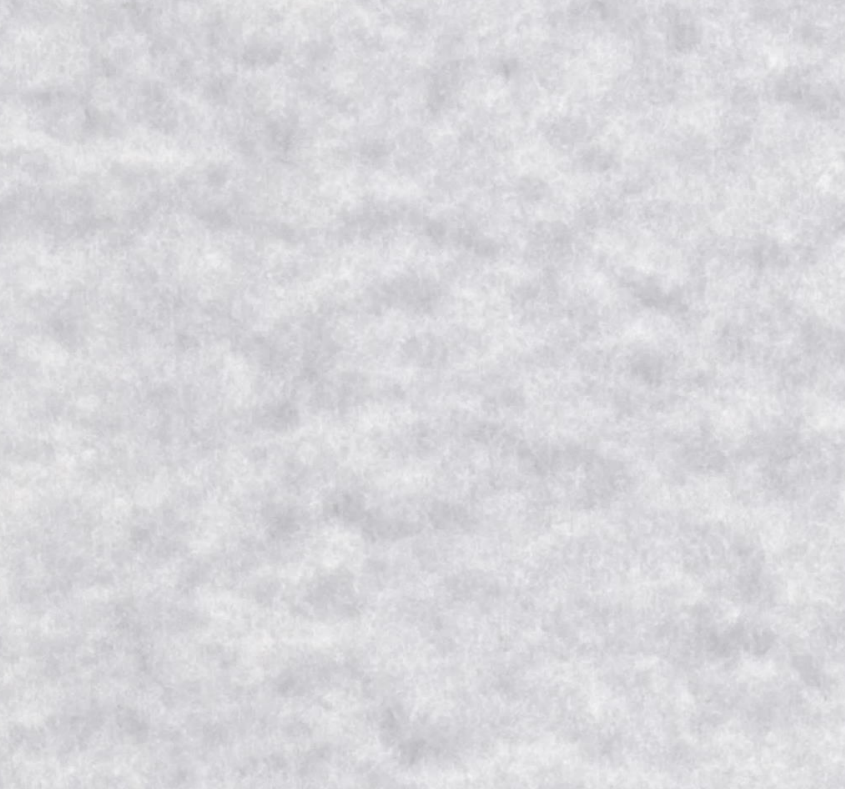


National Aeronautics and Space Administration

Lewis Research Center

Cleveland, Ohio 44135

Official Business

Penalty for Private Use $\$ 300$
FOURTH CLASS MAIL

ADDRESS CORRECTION REQUESTED

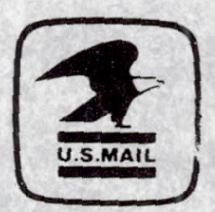

Postage and Fees Paid National Aeronautics and

Space Administration NASA 451 